\title{
Levels and Distribution of Organophosphate Esters (OPEs) in Typical Megacity Wetland Park Landscape Water Bodies in Southwest China
}

Hongling Yin ( $\sim$ belling15@126.com )

Chengdu University of Information Technology https://orcid.org/0000-0002-1662-4673

Liya Liu

Chengdu University of Information Technology

Qin Liu

Chengdu University of Information Technology

Jiaojiao Song

Chengdu University of Information Technology

Shuhong Fang

Chengdu University of Information Technology

Xiaowen Liu

Chengdu University of Information Technology

\section{Research Article}

Keywords: Human activities, organophosphate esters (OPEs), suspended particulate matter (SPM), tris-(2chloroethyl)-phosphate (TCEP) and trichloropropyl phosphate (TCIPP)

Posted Date: June 30th, 2021

DOl: https://doi.org/10.21203/rs.3.rs-649375/v1

License: (9) This work is licensed under a Creative Commons Attribution 4.0 International License.

Read Full License

Version of Record: A version of this preprint was published at Archives of Environmental Contamination and Toxicology on October 28th, 2021. See the published version at https://doi.org/10.1007/s00244-02100899-z. 
1 Levels and distribution of organophosphate esters (OPEs) in typical megacity wetland park

\section{landscape water bodies in Southwest China}

3 Hongling Yin, Liya Liu, Qin Liu, Jiaojiao Song, Shuhong Fang, Xiaowen Liu

\section{Abstract}

5 Human activities have led to the release of organophosphate esters (OPEs) into the environment. This

6 study aims to investigate the levels and partitioning of OPEs in surface water, suspended particulate

7 matter (SPM) and sediments of landscape waters across eleven parks in the city of Chengdu, a

8 megacity in Southwest China. The average concentration of $\Sigma_{6}$ OPEs in the SPM samples (median:

$92.94 \times 10^{3} \mathrm{ng} / \mathrm{L}, 6.88 \times 10^{4} \mathrm{ng} / \mathrm{g} \mathrm{dw}$ ) was $1-3$ orders of magnitude higher than that in the surface water

10 (median: $359 \mathrm{ng} / \mathrm{L}$ ) and sediment (median: $82.8 \mathrm{ng} / \mathrm{g})$ samples. Tri-n-butyl phosphate (TnBP), tris-(2-

11 chloroethyl)-phosphate (TCEP) and trichloropropyl phosphate (TCIPP) were the primary OPE

12 pollutants in the surface water and SPM samples, while TnBP, tris-(2-butoxyethyl) phosphate (TBEP)

13 and tris-(2-ethylhexyl) phosphate (TEHP) predominated the sediment samples. The higher log $K_{\mathrm{oc}}$

14 values of OPEs in park landscape water bodies than other studies in the present study could be

15 explained by the OPE properties ( $f_{\mathrm{oc}}, K_{\mathrm{ow}}$, degradability) and the environmental conditions (the input

16 sources and the hydraulic retention time, etc.).

Hongling Yin

yhl@cuit.edu.cn

College of Resources and Environment, Chengdu University of Information Technology,

Cheng Du, China 


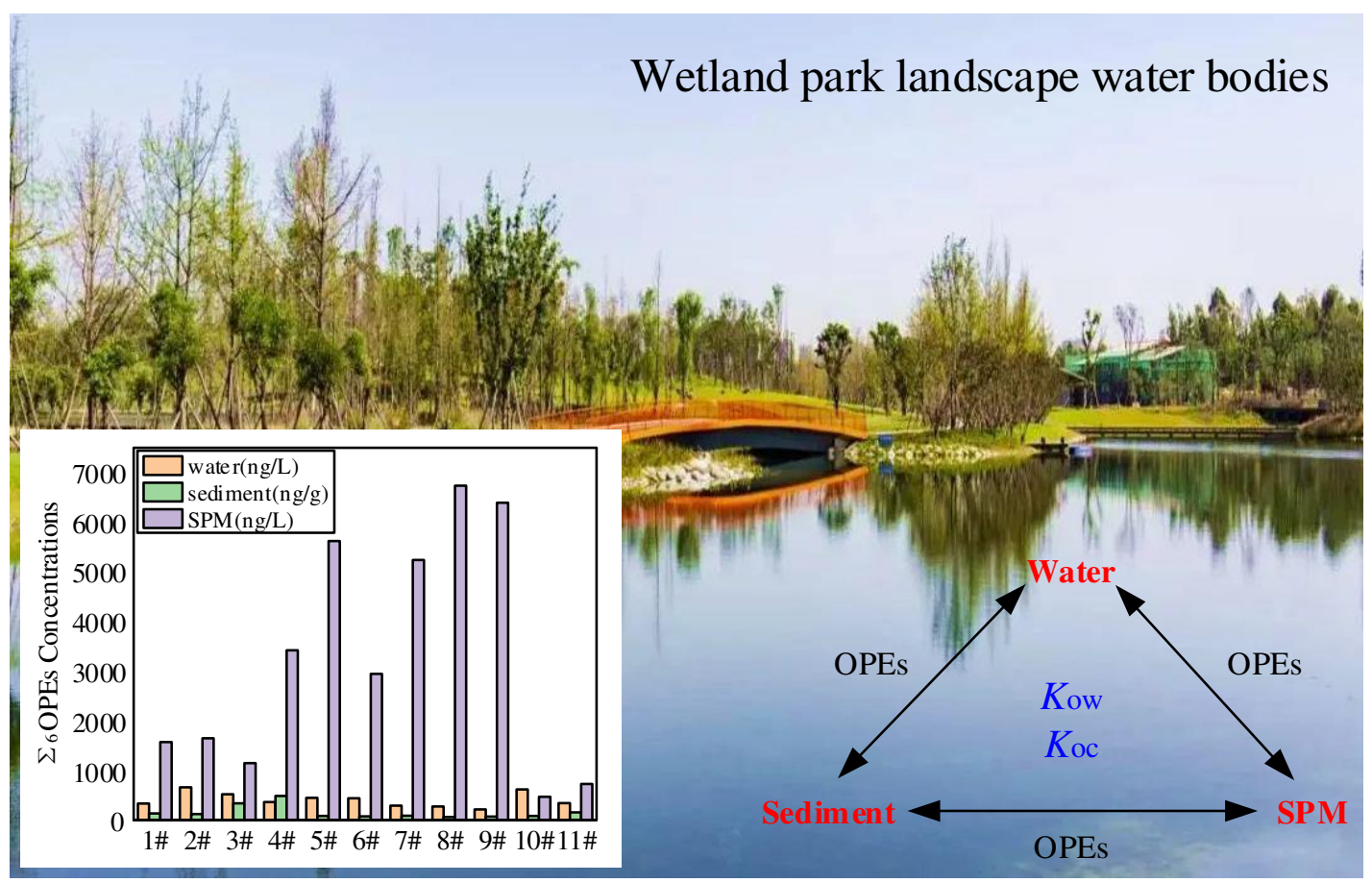


As substitutes for brominated flame retardants, organophosphate esters (OPEs) are important

20 organophosphorus flame retardants. In recent years, due to the large-scale production and use of OPEs

21 worldwide, the accompanying environmental issues have also become increasingly concerning. Some

22 OPEs have been confirmed to have obvious neurotoxicity, reproductive toxicity, carcinogenicity and

23 genotoxicity (Van and Boer, 2012; Du et al. 2015). At present, the occurrence of OPEs has been

24 reported in the air (Takigami et al. 2009; Stapleton et al. 2009; Clark et al. 2017; Yin et al. 2020),

25 wastewater and sludge (Bester et al. 2005; Gao et al. 2016), surface water (Reemtsma et al. 2008;

26 Regnery and Püttmann, 2010; Guo et al. 2017a), sediments (Cao et al. 2012; Cheng et al. 2014; Giulivo

27 et al. 2017), soils (Mihajlovic et al. 2011; Matsukami et al. 2015; Wan et al. 2016; Cui et al. 2017;

28 Deng et al. 2019) and humans (Shah et al. 2006; Schindler et al. 2009), even in remote areas

29 (McDonough et al. 2018). OPEs have become recognized global organic pollutants. As contaminants

30 of emerging concern, OPEs are gradually becoming of research interest to the scientific community. In

31 this paper, alkyl OPEs (TnBP, TBEP, TEHP), chlorinated OPEs (TCEP and TCIPP) and phenyl OPEs

32 (TPhP) were selected because they are widely used in industry and previous studies have shown that

33 their concentrations in all environmental media are relatively high (Bacaloni et al. 2008; Shi et al. 2016;

34 van der Veen and de Boer, 2012; Zhang et al. 2018).

After entering aquatic environments, OPEs endure a series of migration, transformation and

36 bioconcentration related processes. The structural differences among OPEs lead to a variety of

37 chemical and physical properties that result in differences in environmental behaviors. OPEs have only

38 anthropogenic sources as opposed to natural sources, so cities with large populations are potential high-

39 risk areas for OPE pollution in which water bodies are an essential sink of OPEs. Previous studies have 
41 Giulivo et al. 2017; Guo et al. 2017a; Hou et al. 2019; Wu et al. 2019; Zeng et al. 2021), but almost no attention has been paid to urban landscape water bodies. Compared with rivers, urban landscape water has a relatively low flow rate and long water exchange time. The residence time of a relatively open water body ranges from approximately minutes to hours, and the residence time of a semiclosed water body can be hours to days depending on the water temperature. Closed water bodies have limited water exchange, and its retention time is the longest, resulting in its OPE pollution characteristics can reflect emissions from local sources. Therefore, the OPE pollution characteristics and its partitioning behavior in different types of landscape water bodies is of great interest. the Sichuan Province and the only megacity (16.33 million people in 2018) in Southwest China. However, there have been few studies on OPEs in this region. To date, there are 25 parks in Chengdu city, and the landscape water for urban parks covers an area of $6.50 \times 10^{5} \mathrm{~m}^{2}$. This study aims to 1) investigate the pollution levels and characteristics of OPEs in water, suspended particulate matter

54 (SPM) and sediments of representative park landscape waters; 2) analyze the distribution behavior of

55 OPEs in different water bodies; and 3) reveal the relationship between the OPE distribution and its influencing factors. The results can fill knowledge gaps regarding OPE pollution in different phases in

57 the park landscape waters of Southwest China and shed light on their partition behavior, which is of 58 great significance for OPE pollution prevention and control.

\section{Materials and Methods}

\section{Chemicals}



equipment.

\section{Sample Collection}


Moreover, the sampling sites covered different types of landscape water bodies (relatively open: 5\#, 7\#,

samples were wrapped with aluminum foil, sealed in a seal bag, transported to the laboratory as soon as possible and stored in a refrigerator at $-20^{\circ} \mathrm{C}$.

\section{Sample Preparation and Analysis} acetate/acetone $(\mathrm{v} / \mathrm{v}, 4 / 3)$ for elution of the target substances. The eluent was concentrated and the final

101 volume was adjusted to $100 \mu \mathrm{L}$ for gas chromatography-mass spectrometry (GC-MS) analysis.

102 The SPM samples were freeze-dried, soaked in $20 \mathrm{~mL}$ ethyl acetate/acetone (v: v, 3:2) for 12 


$$
K_{\mathrm{a}}=C_{\text {sed }} / C_{\mathrm{w}} \times 1000
$$

$$
K_{\mathrm{b}}=C_{\mathrm{spm}} / C_{\mathrm{w}} \times 1000
$$

$113 K_{\mathrm{a}}$ : equilibrium coefficient between water and SPM $\left(\mathrm{cm}^{3} / \mathrm{g}\right)$,

$114 K_{\mathrm{b}}$ : equilibrium coefficient between water and sediment $\left(\mathrm{cm}^{3} / \mathrm{g}\right)$,

$115 C_{\text {sed }}$ : the content of OPEs in sediment at equilibrium $(\mathrm{ng} / \mathrm{g})$,

$116 C_{\mathrm{spm}}:$ the content of OPEs in SPM at equilibrium $(\mathrm{ng} / \mathrm{g})$,

$117 C_{\mathrm{w}}:$ the content of OPEs in surface water at equilibrium $(\mathrm{ng} / \mathrm{L})$.

$$
K_{\text {oc }}=K_{\text {a(orb) }} \times 100 / f_{\text {oc }}
$$

123 GC was equipped with SH-Rxi-5Sil MS capillary column $(30 \mathrm{~m} \times 0.25 \mu \mathrm{m} \times 0.25 \mathrm{~mm}$, Shimadzu, 
125 electron impact (EI), and it was operated in selected ion monitoring (SIM) mode. The GC oven

126 temperature was held at $50{ }^{\circ} \mathrm{C}$ for 1 minute, increased to $200{ }^{\circ} \mathrm{C}$ at $15{ }^{\circ} \mathrm{C} \mathrm{min}-1$ and held for 1 minute, increased to $250{ }^{\circ} \mathrm{C}$ at $4.00{ }^{\circ} \mathrm{C} \min ^{-1}$, and then increased to $300{ }^{\circ} \mathrm{C}$ at $20{ }^{\circ} \mathrm{C} \min ^{-1}$ and held for 4 minutes. The interface temperature was $280^{\circ} \mathrm{C}$, and the ion source temperature was $200^{\circ} \mathrm{C}$.

\section{Quality Assurance and Quality Control (QA/QC)}

131 evaluate the recovery efficiencies of analytical procedures, internal standard (TPhP- $\left.\mathrm{d}_{15}\right)$ was added in

132 all samples, and the accuracy was evaluated via their recoveries. The concentrations of the 6 OPEs

133 were determined by an external standard method. The correlation coefficients of the standard curves of

134 the six OPE compounds $(0.05-2.00 \mathrm{mg} / \mathrm{L})$ were all higher than 0.99 . The recoveries of the 6 OPEs were

135 determined, ranged from $75 \%$ to $126 \%$ (Table 2). Procedural contamination from the analytical steps

136 aforementioned was evaluated via running a matrix blank with every batch of 10 samples. Only TnBP

137 and TCEP were detected in the blanks, and the levels were $<5 \%$ of the concentrations measured in all

138 samples, which meant that they were negligible. The detection limit of the instrument (LODs) $(\mathrm{S} / \mathrm{N}=3)$

139 ranged from $0.02 \mathrm{mg} / \mathrm{L}$ to $0.04 \mathrm{mg} / \mathrm{L}$ and the instrument precision was $3 \%-7 \%$.

\section{Statistical Analysis}

141 Data analysis was performed using the IBM SPSS 22.0. software. Before statistical analysis, data

142 were tested for normality through Kolmogorov-Smirnoff and Shapiro-Wilk test which showed normal

143 distribution of the data ( $p>0.05$ for all). Analysis of variance (ANOVA) was used to investigate 
144 significant differences in individual OPEs concentrations in different matrix. Correlations between the

145 three environmental phases were analyzed by Pearson's correlation coefficients. For the calculation of

146 OPEs, non-detectable compounds and concentrations below the method detection limit (MDL) were

147 treated as zero. Statistical significance was set as $p<0.05$.

\section{Results and Discussion}

149 Occurrence and Levels of OPEs in Surface Water, SPM and Sediments

150 All OPE compounds had detection rates of $100 \%$ for all SPM samples, while all OPE compounds

151 had an over 50\% detection rate for all water and sediment samples. Although the TCIPP and TPhP had

152 detection rates of $91 \%$ for all water samples, TCIPP (73\%), TBEP (64\%) and TPhP (55\%) had

153 moderate detection rates for sediment samples, and other OPE compounds had detection rates of $100 \%$.

154 High detection rates of OPEs in the aqueous environment indicated that OPE pollution was ubiquitous

155 in the investigated area.

156 The concentrations of $\Sigma_{6} \mathrm{OPEs}$ in the water samples were in the range of 213-658 ng/L, with a

157 median value of $359 \mathrm{ng} / \mathrm{L}$. Compared with OPEs in other lakes and reservoirs, the concentrations of

158 OPEs in the present study were higher than those found in volcanic lakes (average: $165 \mathrm{ng} / \mathrm{L}$ )

159 (Bacaloni et al. 2008) and the Great Lakes (7.3-96 ng/L) (Venier et al. 2014), but two times lower than

160 those in the Pearl River Delta (median concentration: $837 \mathrm{ng} / \mathrm{L}$ ) (Zhang et al. 2018) and one order of

161 magnitude lower than those in found freshwater from Germany (average: $\left.2.06 \times 10^{3} \mathrm{ng} / \mathrm{L}\right)($ Ernst, 1988)

162 and Spain (average: $\left.1.98 \times 10^{3} \mathrm{ng} / \mathrm{L}\right)$ (Cristale et al. 2013). 
164 median value of $82.8 \mathrm{ng} / \mathrm{g}$. The highest concentration of OPEs appeared at site $4 \#$, followed by site $3 \#$,

165 which was highly related to the high density of human activities. The $\Sigma_{6} \mathrm{OPE}$ level in sediment samples

166 is comparable with those from the Pearl River Delta (8.3-470 ng/g) (Tan et al. 2016) in China and the

167 Adige River basin in Italy (11.5-549 ng/g), higher than those in the Evrotas River basin in Greece

168 (10.5-248 ng/g), the Sava River basin in Slovenia (0.31-310 ng/g) (Giulivo et al. 2017), Bui Dau in

169 Vietnam (5-300 ng/g) (Giulivo et al. 2017), Austria (5.74 ng/g) (Matsukami et al. 2016) and Norway

170 (4.98 ng/g) (Martínez-Carballo et al. 2007), but lower than those in the Flanders Rivers in Belgium

171 (673 ng/g) (Green et al. 2008) and the Llobregat River basin in Spain (n.d.- $2.42 \times 10^{3} \mathrm{ng} / \mathrm{g}$ ) (Santín et al.

172 2016).

173 The concentrations of $\Sigma_{6}$ OPEs in SPM varied from 468 to $6.74 \times 10^{3} \mathrm{ng} / \mathrm{L}\left(2.22 \times 10^{4}-7.08 \times 10^{5} \mathrm{ng} / \mathrm{g}\right.$

$174 \mathrm{dw})$, with a median of $2.94 \times 10^{3} \mathrm{ng} / \mathrm{L}\left(6.88 \times 10^{4} \mathrm{ng} / \mathrm{g} \mathrm{dw}\right)$. The highest concentration of OPEs in SPM

175 was observed at site $8 \#$. Site $8 \#$ is in a new wetland park with low population density. However, it is

176 located in a high-tech zone with electronic industry and a large number of new company buildings and

177 industrial parks, which was the cause of high emissions of TnBP and TBEP. Compared with the

178 concentration of traditional brominated flame retardants, the levels of OPEs in SPM in our study were

179 three to five orders of magnitude higher than those in PBDEs found in seawater near Hong Kong (Wurl

180 et al. 2006). A similar trend was found in Dongjiang industrial water (Ruan et al. 2014). The

181 concentration of brominated flame retardants in water was lower than that of OPEs, indicating that

182 OPEs, as substitutes for brominated flame retardants, result in a higher concentration in some

183 environmental media at present. Other researchers have found similar results in which the 

compared to the global lake waters (Bacaloni et al. 2008; Shi et al. 2006; Venier et al. 2014). 
214 found at all sampling sites, and $\Sigma(\mathrm{TnBP}+\mathrm{TBEP}+\mathrm{TEHP})$ accounted for $86 \%$ of the $\Sigma_{6} \mathrm{OPEs}$. The

215 different patterns of OPEs could be attributed to differences in their accumulation features and

216 degradability due to varying physicochemical properties, as well as differences in their production and 217 usage (Wang et al. 2015).

218 To further elucidate the OPE patterns in surface water, sediments and SPM, OPEs were divided 219 into alkyl OPEs (TnBP, TBEP, TEHP), chlorinated OPEs (TCEP and TCIPP) and phenyl OPEs (TPhP).

220 Alkyl OPEs dominated the profile in three phases (water, sediments and SPM), and their percentage in 221 the latter two phases was greater than $85 \%$. Chlorinated OPEs accounted for $43 \%$ of $\Sigma_{6}$ OPEs in the 222 water, but $10 \%$ and $14 \%$ of $\Sigma_{6} \mathrm{OPEs}$ in the SPM and sediment samples, respectively.

224 closed and semiclosed water body categories. 7\# (Donghu Park) and 8\# (Jincheng Park) are relatively 
emission input, complex hydrodynamic conditions and frequent resuspension of OPEs in sediments results in high concentrations of OPEs in SPM and low concentrations in sediments. Sites 3\# and 10\# are typical semiclosed water bodies. Although these two sampling sites have inflows from other tributaries, they could be seen as closed water bodies as a whole. These sites showed higher OPE pollution in the water phases, whereas the concentrations of OPEs in SPM were low. The other sites (12\#, 4\#, 6\#, 10-11\#) are typical closed water bodies. As typical representative closed water body, sites have almost no water exchange, coupled with a long history of pollution and a high density of human activities, resulting in the highest concentrations of OPEs in water and sediments and but low concentrations in SPM.

Distribution of OPEs Between Surface Water, SPM and Sediments

\section{Distribution of OPEs Between Surface Water and SPM}



results differed from the research of Zhang et al (2018) who reported that the significant correlation rivers.

\section{Distribution of OPEs Between Surface Water and Sediments}



not be ignored. These differed from the river or lakes in which the partitioning process was significantly influenced by the contributions of ongoing emissions from the water phase.

\section{Conclusions}

274 Generally, the concentration of OPEs in the surface water and sediment of landscape water in the

275 megacity in Southwest China was at the middle/low level. The $\Sigma_{6} \mathrm{OPE}$ concentration in the SPM was 1-

2763 orders of magnitude higher than that in the surface water and sediments. This phenomenon needs 277 additional attention. and SPM, while TnBP, TBEP and TEHP were dominant in sediments. Alkyl phosphates were the dominant pollutants in the three phases.

281 The calculated $\log K_{\mathrm{oc}}$ in the park landscape water bodies were higher than the rivers reported by

282 the previous studies. Differed from the lakes and rivers, the OPE properties $\left(f_{\text {oc }}, K_{\text {ow }}\right.$, degradability $)$ and

283 the environmental conditions (the input sources and the hydraulic retention time, etc.) mainly influence

284 the partitioning processes of OPEs in different matrix in the park landscape water bodies. Especially,

$285 K_{\text {ow }}$ can partly explain the partitioning process of OPEs between water and sediment samples. The OPE 
286 pollution prevention should be based on the consideration on the changing of the main influencing

287 environmental factors except for the control of the source emissions.

289 Declaration of Interests The authors declare that they have no known competing financial interests or 290 personal relationships that could have appeared to influence the work reported in this paper.

292 Acknowledgements This work was financially supported by the National Natural Science Fund of 293 China (No.41773072, No.21407014) 


\section{References}

Bacaloni A, Cucci F, Guarino C, Nazzari M, Samperi R, Laganà A (2008) Occurrence of organophosphorus flame retardant and plasticizers in three volcanic lakes of central Italy. Environ Sci Technol 42(6):1898-1903. https://doi.org/10.1021/es702549g

Bester K (2005) Comparison of TCIPP concentrations in sludge and wastewater in a typical German sewage treatment plant-comparison of sewage sludge from 20 plants. J Environ Monit 7(5):509513. https://pubs.rsc.org/. https://doi.org/10.1039/b502318a

Cao S, Zeng X, Song H, Li H, Yu Z, Sheng G, Fu J (2012) Levels and distributions of organophosphate flame retardants and plasticizers in sediment from Taihu Lake, China. Environ Toxicol Chem 31(7):1478-1484. https://doi.org/10.1002/etc.1872

Cao D D, Guo J H, Wang Y W, Li Z N, Liang K, Corcoran M B, Hosseini S, Bonina S M C, Rockne K J, Sturchio N C, Giesy J P, Liu J F, Li A (2017) Organophosphate Esters in Sediment of the Great Lakes. Environ Sci Technol 51(3):1441-1449. https://doi.org/10.1021/acs.est.6b05484

Cheng D, Liu X, Wang L, Gong W, Liu G, Fu W, Cheng M (2014) Seasonal variation and sedimentwater exchange of antibiotics in a shallower large lake in North China. Sci Total Environ 476(1):266-275. https://doi.org/10.1016/j.scitotenv.2014.01.010

Clark A E, Yoon S, Sheesley R J, Usenko S (2017) Spatial and temporal distributions of organophosph -ate ester concentrations from atmospheric particulate matter samples collected across Houston, $\mathrm{T}$ X. Environ Sci Technol 51(8):4239-4247. https://doi.org/10.1021/acs.est.7b00115

Cristale J, García V A, Barata C, Lacorte S (2013) Priority and emerging flame retardants in rivers: occurrence in water and sediment, Daphnia magna toxicity and risk assessment. Environ Int 59:232-243. https://doi.org/10.1016/j.envint.2013.06.011

Cui K, Wen J, Zeng F, Li S, Zhou X, Zeng Z (2017) Occurrence and distribution of organophosphate esters in urban soils of the subtropical city, Guangzhou, China. Chemosphere 175:514-520. https://doi.org/10.1016/j.chemosphere.2017.02.070

Deng X, Yin H L, He W L, Luo Y, Wu D, Luo L, Chen J (2019) Distribution and migration of organophosphate in soil and crops in Chengdu City/suburb profile. Environ Chem 38(03):679-685. https://doi.org/10.7524/j.issn.0254-6108.2018042803

Du Z, Wang G, Gao S, Wang Z (2015) Aryl organophosphate flame retardants induced cardiotoxicity during zebrafish embryogenesis: by disturbing expression of the transcriptional regulators. Aquat Toxicol 161:25-32. https://doi.org/10.1016/j.aquatox.2015.01.027

Gao L, Shi Y, Li W, Liu J, Cai Y (2016) Occurrence and distribution of organophosphate triesters and diesters in sludge from sewage treatment plants of Beijing, China. Sci Total Environ 544:143-149. https://doi.org/10.1016/j.scitotenv.2015.11.094

Giulivo M, Capri E, Kalogianni E, Milacic R, Majone B, Ferrari F, Barceló D (2017) Occurrence of hal -ogenated and organophosphate flame retardants in sediment and fish samples from three Europea n river basins. Sci Total Environ 586:782-791. https://doi.org/10.1016/j.scitotenv.2017.02.056

Green N, Schlabach M, Bakke T, Brevik E M, Dye C, Herzke D, Huber S, Plosz B, Remberger M, Schoyen M, Uggerud H T, Vogelsang C (2008) Screening of selected metals and new organic contaminants. Norwegian Pollution Control Agency. https://www.researchgate.net/publication 
Guo J, Romank K, Westenbroek S, Hites R A, Venier M (2017a) Current use flame retardants in the water of Lake Michigan tributaries. Environ Sci Technol 51(17):9960-9969. https://doi.org/10.1021 /acs.est.7b01294

Hou L, Jiang J, Gan Z, Dai Y Y, Yang P, Yan Y, Ding S, Su S J, Bao X M (2019) Spatial distribution o -f organophosphorus and brominated flame retardants in surface water, sediment, groundwater, an d wild fish in Chengdu, China. Arch Environ Contam Toxicol 77:279-290. https://doi.org/10.1007 /s00244-019-00624-X

Martínez-Carballo E, González-Barreiro C, Sitka A, Scharf S, Gans O (2007) Determination of selected organophosphate esters in the aquatic environment of Austria. Sci Total Environ 388(1):290-299. https://doi.org/10.1016/j.scitotenv.2007.08.005

Matsukami H, Tue N, Suzuki G, Someya M, Tuyen L H, Viet P H, Takahashi S, Tanabe S, Takigami H (2015) Flame retardant emission from e-waste recycling operation in northern Vietnam: environmental occurrence of emerging organophosphorus esters used as alternatives for PBDEs. Sci Total Environ 514:492-499. https://doi.org/10.1016/j.scitotenv.2015.02.008

Matsukami H, Suzuki G, Tue N M, Tuyenle H, Viet P H, Takahashi S, Tanabe S, Takigami H (2016) Analysis of monomeric and oligomeric organophosphorus flame retardants in fish muscle tissues using liquid chromatograph electrospray ionization tandem mass spectrometry: application to Nile tilapia (Oreochromis niloticus) from an e-waste processing area in northern Vietnam. Emerg Contam 2(2):89-97. https://doi.org/10.1016/j.emcon.2016.03.004

McDonough C A, De Silva A O, Sun C, Cabrerizo A, Adelman D, Soltwedel T, Bauerfeind E, Muir D C G, Lohmann R (2018) Dissolved organophosphate esters and polybrominated diphenyl ethers in remote marine environments: Arctic surface water distributions and net transport through Fram Strait. Environ Sci Technol 52(11):6208-6216. https://doi.org/10.1021/acs.est.8b01127

Mihajlovic I, Miloradov M V, Fries E (2011) Application of Twisselmann extraction, SPME, and GCMS to assess input sources for organophosphate esters into soil. Environ Sci Technol 45(6):22642269. https://doi.org/10.1021/es103870f

Reemtsma T, Quintana J B, Rodil R, Garc1'a-Lo'pez M, Rodrı'guez I (2008) Organophosphorus flame retardants and plasticizers in water and air I. Occurrence and fate. Trends Analyt Chem 27(9):727-737. https://doi.org/10.1016/j.trac.2008.07.002

Regnery J, Püttmann W (2010) Seasonal fluctuations of organophosphate concentrations in precipitatio -n and storm water runoff. Chemosphere 78(8):958-964. https://doi.org/10.1016/j.chemosphere.20 09.12.027

Rodil R, Quintana J B, Concha-Graña E, López-Mahía P, Muniategui-Lorenzo S, Prada-Rodríguez D (2012) Emerging pollutants in sewage, surface and drinking water in Galicia (NW Spain). Chemosphere 86(10):1040-1049. https://doi.org/10.1016/j.chemosphere.2011.11.053

Ruan W, Tan X, Luo X (2014) Organophosphorus flame retardants in surface sediments of Dongjiang River. China environmental science 34:2394-2400. https://doi.org/10.3969/j.issn.1000-6923.2014. 09.042

Santín G, Eljarrat E, Barceló D (2016) Simultaneous determination of 16 organophosphorus flame retardants and plasticizers in fish by liquid chromatography-tandem mass spectrometry. J Chromatogr A 1441:34-43. https://doi.org/10.1016/j.chroma.2016.02.058 
Schindler B K, FÖrster K, Angerer J (2009) Determination of human urinary organophosphate flame retardant metabolites by solid-phase extraction and gas chromatography-tandem mass spectrometry. J Chromatogr B 877(4):375-381. https://doi.org/10.1016/j.jchromb.2008.12.030

Shah M, Meija J, Cabovska B, Caruso J A (2006) Determination of phosphoric acid triesters in human plasma using solid-phase microextraction and gas chromatography coupled to inductively coupled plasma mass spectrometry. J Chromatogr A 1103(2):329-336. https://doi.org/10.1016/j.chroma.2 005.11.042

Shi Y, Gao L, Li W (2016) Occurrence distribution and seasonal variation of organophosphate flame retardants and plasticizers in urban surface water in Beijing, China. Environ Pollut 209:1-10. https://doi.org/10.1016/j.envpol.2015.11.008

Stapleton H M, Klosterhaus S, Eagle S, Fuh J, Meeker J D, Blum A, Webster T F (2009) Detection of organophosphate flame retardants in furniture foam and U.S. house dust. Environ Sci Technol 43(19):7490-7495. https://doi.org/10.1021/es9014019

Takigami H, Suzuki G, Hirai Y, Ishikawa Y, Sunami M, Sakai S I (2009) Flame retardants in indoor du st and air of a hotel in Japan. Environ Int 35(4):688-693. https://doi.org/10.1016/j.envint.2008.12. 007

Tan X X, Luo X J, Zheng X B, Li Z R, Sun R X, Mai B X (2016) Distribution of organophosphorus flame retardants in sediments from the Pearl River Delta in South China. Sci Total Environ 544:77-84. https://doi.org/10.1016/j.scitotenv.2015.11.089

US EPA (2012) Estimation Programs Interface Suite for Microsoft Windows, v. U. S. E. P. A, Washington, DC, USA.

Van der Veen I, de Boer D (2012) Phosphorus flame retardants: properties, production,environmental o -ccurrence, toxicity and analysis. Chemosphere 88(10):1119-1153. https://doi.org/10.1016/j.chem osphere.2012.03.067

Venier M, Dove A, Romanak K, Backus S, Hites R (2014) Flame retardants and legacy chemicals in Great Lakes' water. Environ Sci Technol 48(16):9563-9572. https://doi.org/10.1021/es501509r

Wan W, Zhang S, Huang H, Wu T (2016) Occurrence and distribution of organophosphorus esters in soils and wheat plants in a plastic waste treatment area in China. Environ Pollut 214:349-353. https://doi.org/10.1016/j.envpol.2016.04.038

Wang R, Tang J, Xie Z, Mi W, Chen Y, Wolschke H, Ebinghaus R (2015) Occurrence and spatial distri -bution of organophosphate ester flame retardants and plasticizers in 40 rivers draining into the Bo -hai Sea, north China. Environ Pollut 198:172-178. https://doi.org/10.1016/j.envpol.2014.12.037

Wang T, Ding N, Wang T, Chen S J, Luo X J, Mai B X (2018) Organophosphorus esters (OPEs) in $\mathrm{PM}_{2.5}$ in urban and e-waste recycling regions in southern China: concentrations, sources, and emissions. Environ Res 167:437-444. https://doi.org/10.1016/j.envres.2018.08.015

Wang X, Zhu L, Zhong W, Yang L (2018) Partition and source identification of organophosphate esters in the water and sediment of Taihu Lake, China. J Hazard Mater 360:43-50. https://doi.org/10.1016/j.jhazmat.2018.07.082

Wu D, Yin H L, Li S P, Wang Z W, Deng X, Luo Y, Luo L (2019) Pollution characteristics of organophosphates in surface water and sediment of Jinjiang River in Chengdu. Environ Sci 40(3):1245-1251. https://doi.org/10.13227/j.hjkx.201808038 
Wurl O, Lam P K S, Obbard J P (2006) Occurrence and distribution of polybrominated diphenyl ethers (PBDEs) in the dissolved and suspended phases of the sea-surface microlayer and seawater in Hon -g Kong, China. Chemosphere 65(9):1660-1666. https://doi.org/10.1016/j.chemosphere.2006.02.0 24

Wurl O, Obbard J P, Lam P K S (2006) Distribution of organochlorines in the dissolved and suspended phase of the sea-surface microlayer and seawater in Hong Kong, China. Mar Pollut Bull 52(7):768-777. https://doi.org/10.1016/j.marpolbul.2005.11.024

Yin H L, Liang J F, Wu D, Li S P, Luo Y, Deng X (2020) Measurement report: seasonal, distribution and sources of organophosphate esters in $\mathrm{PM}_{2.5}$ from an inland urban city in southwest China. Atmos Chem Phys 20(23):14933-14945. https://doi.org/10.5194/acp-20-14933-2020

Yin H L, Liu Q, Deng X, Liu X W, Fang S H, Xiong Y M, Song J J (2021) Organophosphates (OPEs) in water, suspended particulate matter (SPM) and sediments of the Minjiang River. China Chinese Chemical Letters. https://doi.org/10.1016/j.cclet.2021.02.023

Zeng J M, Zhong S H, Qian W, Yuan S W, Zhu X S (2021) Pollution status and biological toxicity of o -rganophosphate in water environment. Environ Sci. https://doi.org/10.19674/j.cnki.issn1000-692 3.20210324 .004 phosphate flame retardants (PFRs) in water environment. Sci Total Environ 630:164-170. https://doi.org/10.1016/j.scitotenv.2018.02.215 
436 Table 1 Information about the sampling sites.

437 Table 2 Recoveries of OPEs in each medium.

438 Table 3 The obtained $\log K_{\mathrm{oc}}$ between water-SPM and water-sediment.

439

440 Table 1 Information about the sampling sites.

\begin{tabular}{|c|c|c|c|c|c|}
\hline Number & Location & $\begin{array}{l}\text { Latitude and } \\
\text { longitude }\end{array}$ & Position & Water type & $\overline{\operatorname{Aera}\left(\mathrm{km}^{2}\right)}$ \\
\hline $1 \#$ & Lianghe City Park & $\begin{array}{c}30^{\circ} 41^{\prime} 55^{\prime \prime} \mathrm{N} \\
104^{\circ} 02^{\prime} 54^{\prime \prime} \mathrm{E}\end{array}$ & Northwest & Closed & 4.44 \\
\hline 2\# & $\begin{array}{c}\text { Fenghuangshan } \\
\text { Park }\end{array}$ & $\begin{array}{l}30^{\circ} 75^{\prime} 20^{\prime \prime} \mathrm{N} \\
104^{\circ} 08^{\prime} 72^{\prime \prime} \mathrm{E}\end{array}$ & North & Closed & 10 \\
\hline $3 \#$ & Shahe Park & $\begin{array}{l}30^{\circ} 42^{\prime} 58^{\prime \prime} \mathrm{N} \\
104^{\circ} 04^{\prime} 10^{\prime \prime} \mathrm{E}\end{array}$ & North & Semiclosed & -- \\
\hline $4 \#$ & $\begin{array}{c}\text { Jinghu, Southwest } \\
\text { Jiaotong } \\
\text { University }\end{array}$ & $\begin{array}{l}30^{\circ} 39^{\prime} 35^{\prime \prime} \mathrm{N} \\
104^{\circ} 03^{\prime} 10^{\prime \prime} \mathrm{E}\end{array}$ & North & Closed & -- \\
\hline $5 \#$ & Huanhuaxi Park & $\begin{array}{l}30^{\circ} 39^{\prime} 38^{\prime \prime} \mathrm{N} \\
104^{\circ} 01^{\prime} 43^{\prime \prime} \mathrm{E}\end{array}$ & Center & Relatively open & 0.32 \\
\hline $6 \#$ & The people's Park & $\begin{array}{l}30^{\circ} 39^{\prime} 31^{\prime \prime} \mathrm{N} \\
104^{\circ} 03^{\prime} 19^{\prime \prime} \mathrm{E}\end{array}$ & Center & Closed & 0.11 \\
\hline $7 \#$ & East Lake Park & $\begin{array}{c}30^{\circ} 37^{\prime} 14^{\prime \prime} \mathrm{N} \\
104^{\circ} 05^{\prime} 02^{\prime \prime} \mathrm{E}\end{array}$ & Southeast & Relatively open & 1.52 \\
\hline $8 \#$ & Jincheng Park & $\begin{array}{l}30^{\circ} 34^{\prime} 15^{\prime \prime} \mathrm{N} \\
104^{\circ} 03^{\prime} 10^{\prime \prime} \mathrm{E}\end{array}$ & South & Relatively open & 1.6 \\
\hline 9\# & Daguanyan & $\begin{array}{l}30^{\circ} 37^{\prime} 07^{\prime \prime} \mathrm{N} \\
104^{\circ} 07^{\prime} 38^{\prime \prime} \mathrm{E}\end{array}$ & Southeast & Closed & -- \\
\hline $10 \#$ & $\begin{array}{c}\text { Bailu Bay } \\
\text { Wetland Park }\end{array}$ & $\begin{array}{c}30^{\circ} 34^{\prime} 05^{\prime \prime} \mathrm{N} \\
104^{\circ} 07^{\prime} 45^{\prime \prime} \mathrm{E}\end{array}$ & Southeast & Semiclosed & 2 \\
\hline $11 \#$ & $\begin{array}{l}\text { Qinglong Lake } \\
\text { Wetland Park }\end{array}$ & $\begin{array}{l}30^{\circ} 38^{\prime} 36^{\prime \prime} \mathrm{N} \\
104^{\circ} 11^{\prime} 10^{\prime \prime} \mathrm{E}\end{array}$ & Southeast & Closed & 20 \\
\hline
\end{tabular}

\section{1}

442 Table 2 Recoveries of OPEs in each medium.

\begin{tabular}{llll}
\hline compounds & Water & SPM & Sediments \\
\hline TnBP & $90 \sim 111 \%$ & $82 \sim 130 \%$ & $89 \sim 112 \%$ \\
TCEP & $81 \sim 102 \%$ & $90 \sim 112 \%$ & $83 \sim 108 \%$ \\
TCIPP & $75 \sim 91 \%$ & $81 \sim 115 \%$ & $84 \sim 99 \%$ \\
TDCPP & $90 \sim 116 \%$ & $85 \sim 120 \%$ & $103 \sim 119 \%$ \\
TPhP & $83 \sim 99 \%$ & $96 \sim 110 \%$ & $76 \sim 117 \%$ \\
TBEP & $92 \sim 108 \%$ & $82 \sim 109 \%$ & $80 \sim 103 \%$ \\
TEHP & $91 \sim 114 \%$ & $75 \sim 98 \%$ & $89 \sim 126 \%$ \\
\hline
\end{tabular}

443

444 Table 3 The obtained $\log K_{\mathrm{oc}}$ between water-SPM and water-sediment.

\begin{tabular}{cccccccccccc}
\hline & \multicolumn{10}{c}{ Log $K_{\mathrm{oc}}$ between water and SPM } \\
& $1 \#$ & $2 \#$ & $3 \#$ & $4 \#$ & $5 \#$ & $6 \#$ & $7 \#$ & $8 \#$ & $9 \#$ & $10 \#$ & $11 \#$ \\
\hline TnBP & 6.21 & 5.80 & 5.74 & 6.70 & 6.41 & 6.07 & 6.74 & 7.11 & 5.17 & 5.00 & 5.34 \\
TCEP & 5.69 & 5.57 & 5.23 & 6.45 & 5.95 & 5.44 & 5.99 & 6.78 & 4.72 & 4.66 & 5.79 \\
TCPP & 5.07 & 4.55 & 4.81 & 5.33 & 4.55 & 4.69 & 6.19 & 5.83 & -- & 4.35 & 4.92
\end{tabular}




\begin{tabular}{cccccccccccc} 
TPhP & 5.59 & 5.12 & 5.30 & 5.69 & 5.26 & 5.27 & 5.57 & 6.21 & -- & 5.31 & 5.35 \\
TBEP & 5.57 & 5.86 & 5.73 & 5.96 & 5.65 & 5.49 & 5.68 & 7.03 & 5.28 & 5.74 & 5.78 \\
TEHP & 5.56 & 5.40 & 5.44 & 5.80 & 5.21 & 5.27 & 5.72 & 6.53 & 5.24 & 5.33 & 5.40 \\
mean & 5.62 & 5.38 & 5.38 & 5.99 & 5.51 & 5.37 & 5.98 & 6.58 & 5.10 & 5.07 & 5.43 \\
\hline \multicolumn{7}{c}{ Log $K_{\text {oc }}$ between water } & and sediment \\
& $1 \#$ & $2 \#$ & $3 \#$ & $4 \#$ & $5 \#$ & $6 \#$ & $7 \#$ & $8 \#$ & $9 \#$ & $10 \#$ & $11 \#$ \\
\hline TnBP & 4.61 & 4.98 & 4.41 & 4.80 & 4.42 & 4.50 & 4.22 & 4.69 & 4.15 & 4.55 & 5.04 \\
TCEP & 3.70 & 4.08 & 3.92 & 3.84 & 3.48 & 3.92 & 4.27 & 5.18 & 4.42 & 4.32 & 4.46 \\
TCPP & 3.77 & 3.89 & -- & 3.13 & 3.49 & 4.22 & 4.28 & -- & -- & 4.34 & 4.10 \\
TPhP & 4.51 & -- & 3.99 & 4.08 & -- & 5.00 & 4.90 & -- & -- & 5.14 & -- \\
TBEP & -- & -- & 5.08 & 3.91 & -- & 4.96 & 4.88 & -- & 4.15 & 5.07 & 4.71 \\
TEHP & 4.54 & 4.82 & 4.51 & 3.90 & 4.36 & 4.94 & 4.61 & 5.42 & 4.23 & 5.42 & 4.68 \\
mean & 4.23 & 4.44 & 4.38 & 3.94 & 3.94 & 4.59 & 4.53 & 5.10 & 4.24 & 4.81 & 4.60 \\
\hline
\end{tabular}


$447 \quad$ Fig. 1 Map of sampling sites.

448 Fig. 2 Correlations between the $\log K_{\text {oc }}$ values of OPEs and their $\log K_{\text {ow }}$ in water and SPM (black

449 square: the present study; blue squre: the study of Zhang et al. 2018).

450 Fig. 3 Correlations between the $\log K_{\text {oc }}$ values of OPEs and their $\log K_{\text {ow }}$ in water and sediments (black 451 squre: the present study; pink squre: the study of Wang et al. 2018).

452 Fig. 4 Correlations between the $\log K_{\text {oc }}$ values of OPEs and their $\log K_{\text {ow }}$ in water and sediments (only 453 for site $10 \#)$.

454

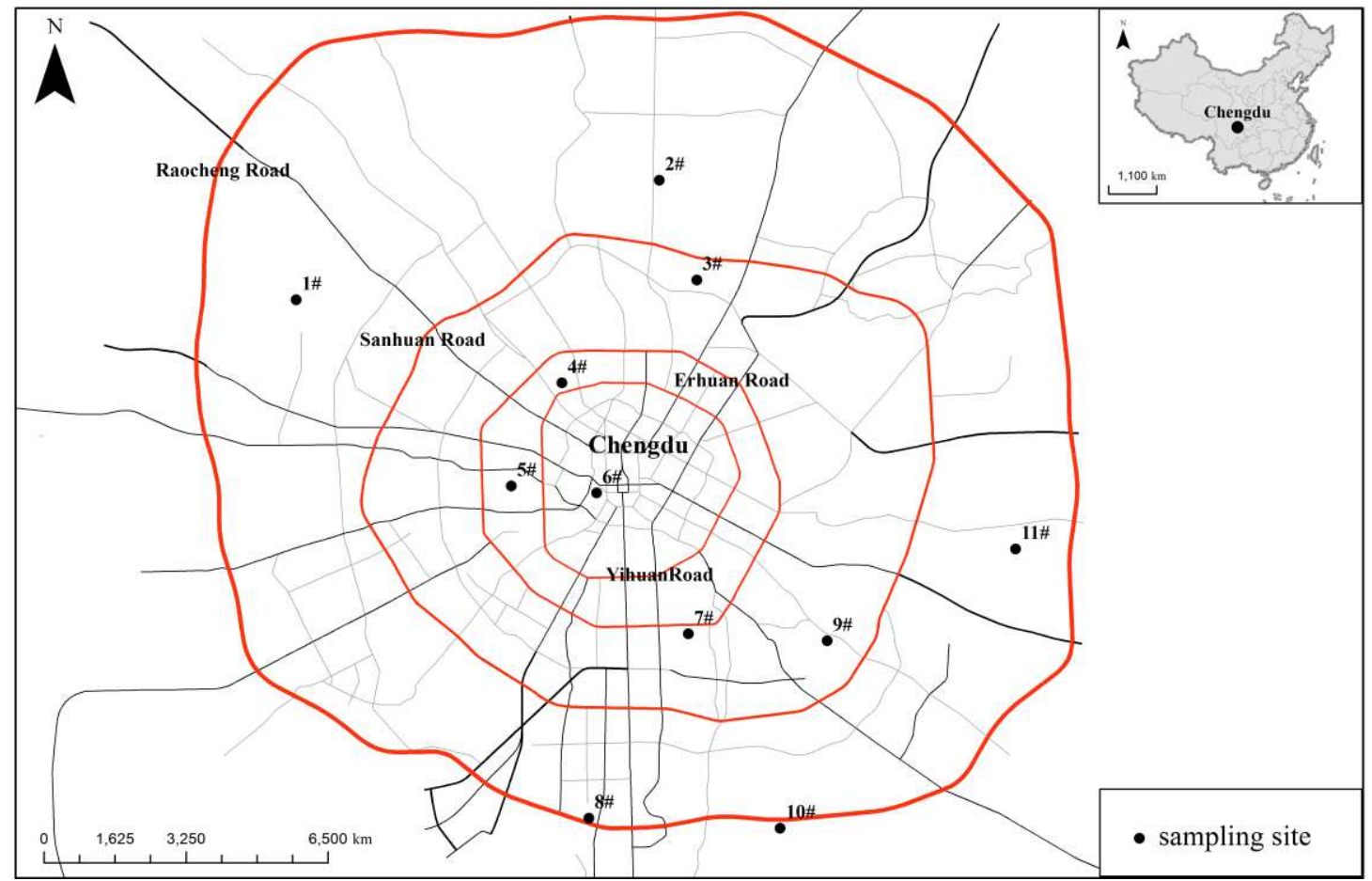

456 Fig. 1 Map of sampling sites. 


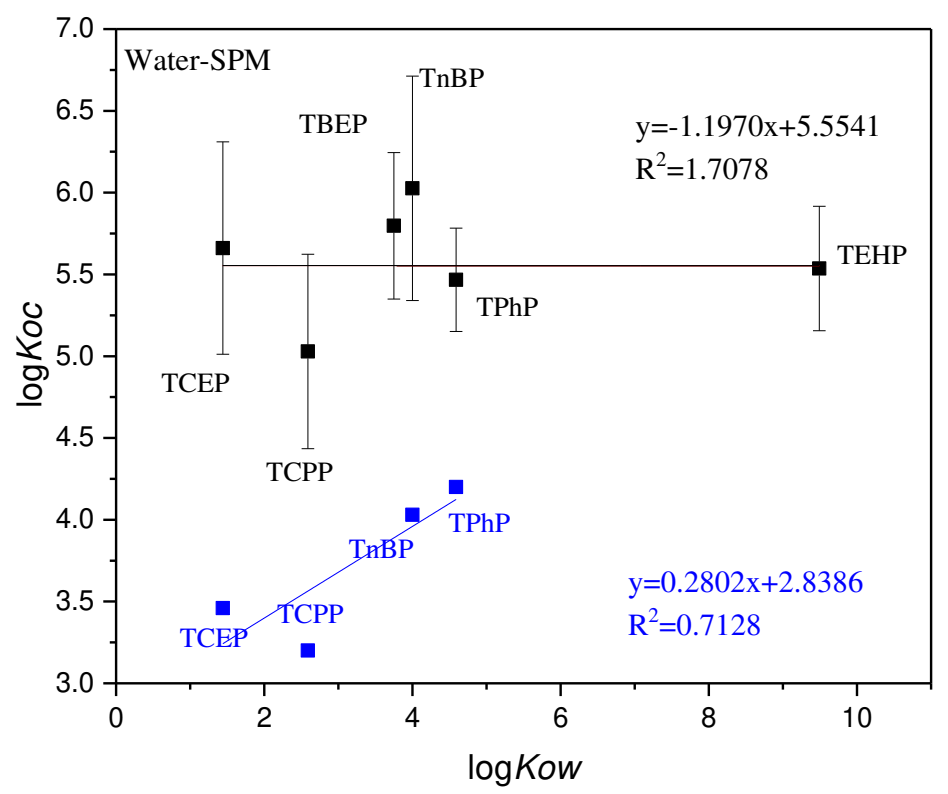

457

Fig. 2 Correlations between the $\log K_{\text {oc }}$ values of OPEs and their $\log K_{\text {ow }}$ in water and SPM (black square: the present study; blue squre: the study of Zhang et al. 2018).

460

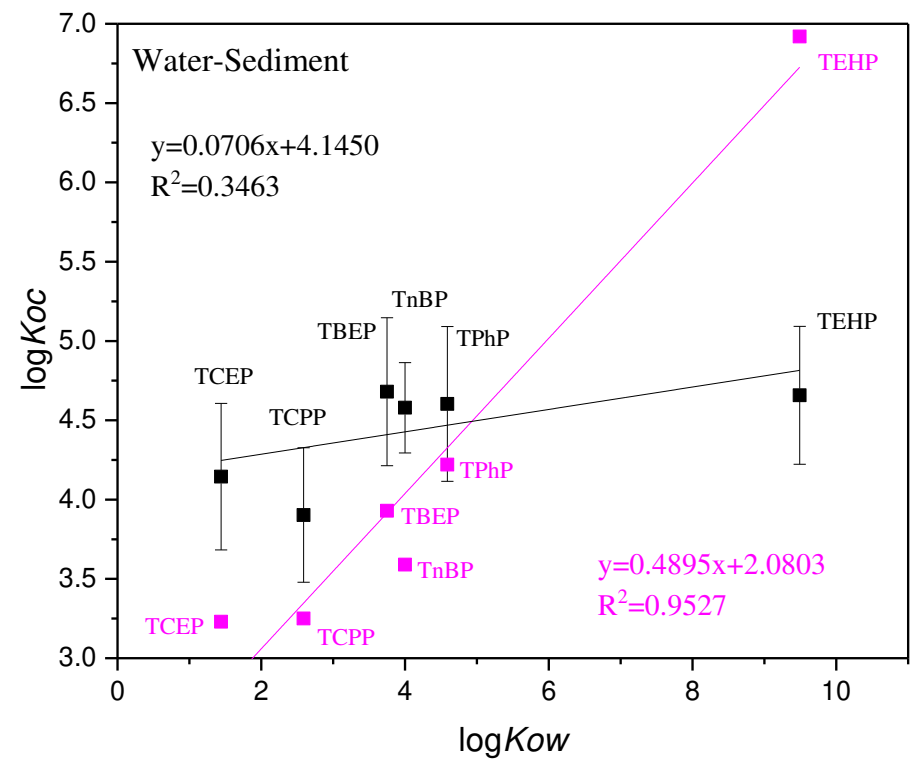

462 Fig. 3 Correlations between the $\log K_{\text {oc }}$ values of OPEs and their $\log K_{\text {ow }}$ in water and sediments (black 463 squre: the present study; pink squre: the study of Wang et al. 2018). 


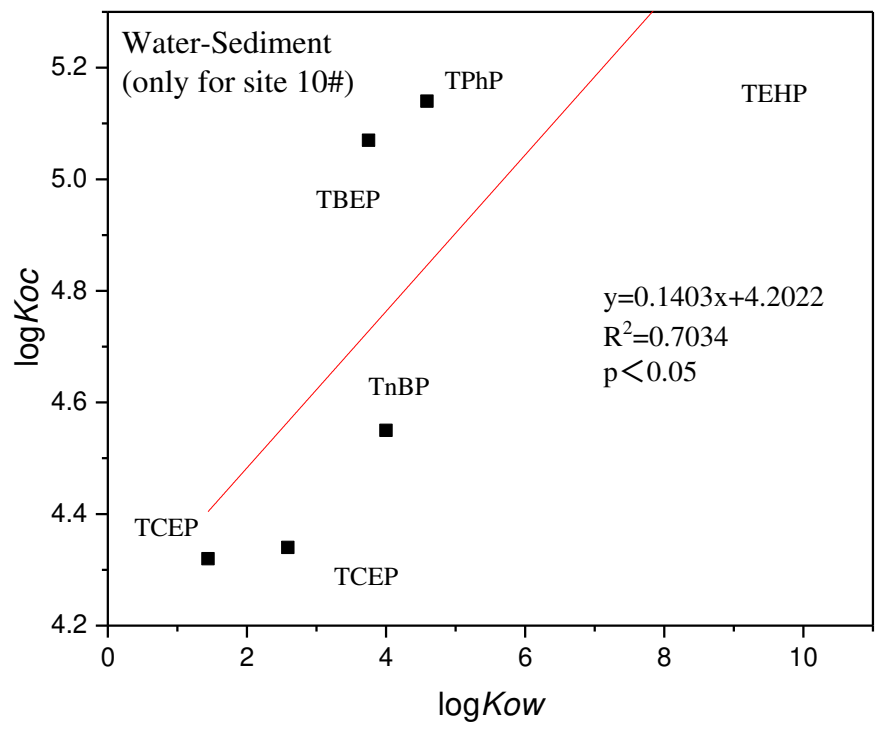

465 Fig. 4 Correlations between the $\log K_{\mathrm{oc}}$ values of OPEs and their $\log K_{\mathrm{ow}}$ in water and sediments (only

466 for site 10\#).

467

468 Supplementary Table and Figure

469 Table S1 Correlations between water, sediments and SPM.

470 Fig. S1 Correlation between the $\log K_{\mathrm{a}}$ and $\log K_{\mathrm{b}}$.

471

472 Table S1 Correlations between water, sediments and SPM.

\begin{tabular}{|c|c|c|c|c|c|c|c|c|c|}
\hline & & water & sediment & SPM & & & water & sediment & SPM \\
\hline \multirow{3}{*}{$1 \#$} & water & 1 & $.873^{*}$ & $.880^{*}$ & \multirow{3}{*}{ 4\# } & water & 1 & .689 & .690 \\
\hline & sediment & $.873^{*}$ & 1 & $.990^{* * *}$ & & sediment & .689 & 1 & $.998^{* *}$ \\
\hline & SPM & $.880^{*}$ & $.990^{* *}$ & 1 & & SPM & .690 & $.998^{* *}$ & 1 \\
\hline \multirow{3}{*}{$2 \#$} & water & 1 & .549 & .459 & \multirow{3}{*}{$5 \#$} & water & 1 & .633 & .552 \\
\hline & sediment & .549 & 1 & $.975^{* *}$ & & sediment & .633 & 1 & $.983^{* *}$ \\
\hline & SPM & .459 & $.975^{* *}$ & 1 & & SPM & .552 & $.983^{* *}$ & 1 \\
\hline \multirow{4}{*}{$3 \#$} & water & 1 & .197 & .597 & \multirow{3}{*}{$6 \#$} & water & 1 & $.881^{*}$ & $.877^{*}$ \\
\hline & sediment & .197 & 1 & .778 & & sediment & $.881^{*}$ & 1 & $.948^{* *}$ \\
\hline & SPM & .597 & .778 & 1 & & SPM & $.877^{*}$ & $.948^{* *}$ & 1 \\
\hline & & water & sediment & SPM & & & water & sediment & SPM \\
\hline \multirow{3}{*}{ 7\# } & water & 1 & .551 & $.895^{*}$ & \multirow{3}{*}{$10 \#$} & water & 1 & $.823^{*}$ & .250 \\
\hline & sediment & .551 & 1 & .572 & & sediment & $.823^{*}$ & 1 & .659 \\
\hline & SPM & $.895^{*}$ & .572 & 1 & & SPM & .250 & .659 & 1 \\
\hline \multirow{3}{*}{$8 \#$} & water & 1 & .241 & .775 & \multirow{3}{*}{$11 \#$} & water & 1 & $.822^{*}$ & .679 \\
\hline & sediment & .241 & 1 & .457 & & sediment & $.822^{*}$ & 1 & $.875^{*}$ \\
\hline & SPM & .775 & .457 & 1 & & SPM & .679 & $.875^{*}$ & 1 \\
\hline 9\# & water & 1 & $.981^{* *}$ & $.894^{*}$ & Total & water & 1 & .685 & .735 \\
\hline
\end{tabular}




\begin{tabular}{cccccccc} 
sediment & $.981^{* *}$ & 1 & $.850^{*}$ & sediment & .685 & 1 & $.991^{* *}$ \\
SPM & $.894^{*}$ & $.850^{*}$ & 1 & SPM & .735 & $.991^{* *}$ & 1 \\
\hline
\end{tabular}

473

**. $p<0.01$ (2-tailed)

$474 * . p<0.05$ (2-tailed)

475

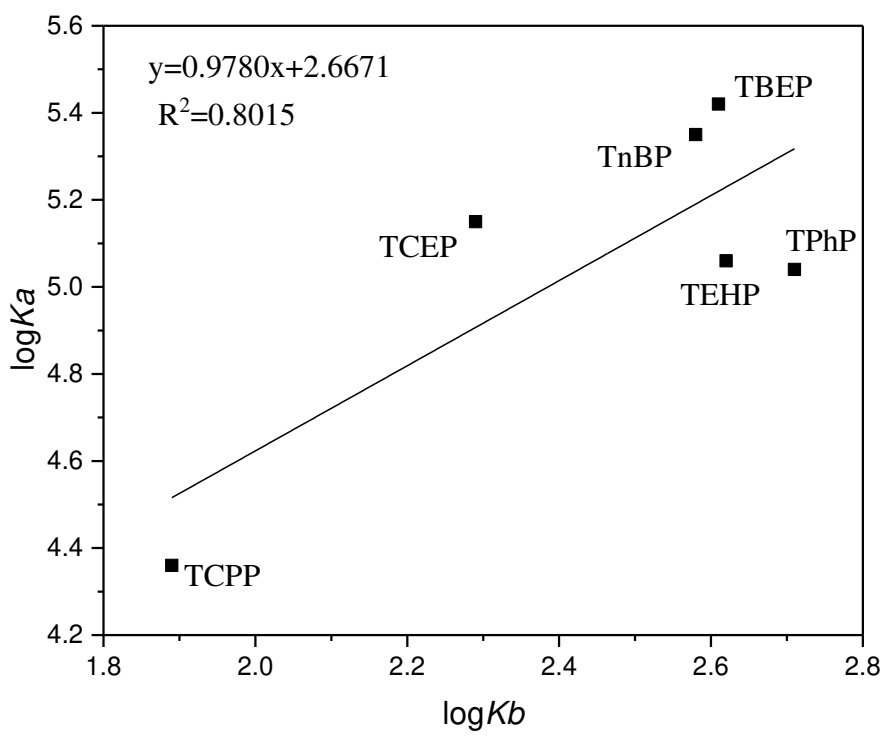

476

477 Fig. S1 Correlation between the $\log K_{\mathrm{a}}$ and $\log K_{\mathrm{b}}$. 


\section{Supplementary Files}

This is a list of supplementary files associated with this preprint. Click to download.

- SupplementaryTableandFigure.docx

- Supplementaldata.xlsx

- 1.jpg 